\title{
CBLC wt Allele
}

National Cancer Institute

\section{Source}

National Cancer Institute. CBLC wt Allele. NCI Thesaurus. Code C97440.

Human CBLC wild-type allele is located in the vicinity of $19 q 13.2$ and is approximately 23 $\mathrm{kb}$ in length. This allele, which encodes E3 ubiquitin-protein ligase CBL-C protein, plays a role in the modulation of signal transduction. Mutation of the gene may be associated with acute myeloid leukemia. 